\title{
ISLAM DAN OTORITAS KEAGAMAAN
}

\author{
Rumadi \\ UIN Syarif Hidayatullah Jakarta \\ e-mail: rumadi_hasan@yahoo.com
}

\begin{abstract}
Is religion possible to grow without any authority? Generally people responded the question with two speculative answers: "religion can be and grow without any authority" and "religion can not be and grow without any authority". The first opinion is based on the argumentation that religion constitutes a divine total comprehension. It does not need any other than the submission of human being to God. Meanwhile, the second opinion is based on the argumentation that religion constitutes individual rights to communicate and submit to God, but in social sphere the development of religion needs "distributors" having credibility to speak and transmit religious messages. However, in fact, religious authority is not a static one, but dynamic. Levels of religious authority and inter relation between the authority levels is a part of the dynamics.
\end{abstract}

\begin{abstract}
$* * *$
Mungkinkah agama tumbuh tanpa otoritas?Pada umumnya jawaban atas pertanyaan ini ada dua:"agama dapat tumbuh tanpa otoritas" dan "agama tidak dapat tumbuh tanpa otoritas", Pandangan pertama didasarkan pada argumentasi bahwa agama merupakan pemahaman total terhadap ketuhanan. Yang dibutuhkan dalam konteks ini adalah ketundukan terhadap Tuhan semata. Sementara pandangan kedua didasarkan pada argumentasi bahwa agama merupakan hak individual untuk berkomunikasi dan menyerahkan diri kepada Tuhan,namun di dalam lingkup sosial perkembangan agama membutuhkan "penyebar" yang memiliki kredibilitas untuk berbicara dan menyampaikan pesan-pesan agama. Namun demikian, dalam kenyataannya otoritas agama bukan merupakan hal yang statis, namun dinamis. Tingkat otoritas keagamaan dan inter relasi antar tingkat-tingkat otoritas merupakan bagian dari dinamika tersebut.
\end{abstract}

Keywords: otoritas, wacana keagamaan, otoritas keagamaan, otoritas politik 


\section{A. Pendahuluan}

Saya ingin mengawali tulisan ini dengan pertanyaan: mungkinkah agama bisa hidup dan berkembang tanpa adanya otoritas? Pertanyaan ini setidaknya akan memunculkan dua spekulasi jawaban: "agama bisa hidup dan berkembang tanpa otoritas" dan "agama tidak tidak bisa hidup tanpa otoritas". Pandangan pertama didasarkan pada argumentasi bahwa agama merupakan bentuk penghayatan ke-Tuhan-an. Ia tidak membutuhkan apaapa kecuali ketundukan manusia pada Tuhan itu sendiri. Kalau pun ada tokoh-tokoh agama, ia sama sekali tidak bisa mewakili kehadiran Tuhan yang hal itu ada dalam dada pemeluk agama. Tokoh-tokoh agama hanya diperlukan untuk melakukan mobilisasi sosial sebagai bentuk dan ekspresi solidaritas keagamaan.

Sedang jawaban kedua didasarkan argumentasi: memang agama merupakan hak individu untuk berkomunikasi dan ketundukan pada Tuhan, namun dalam kenyataan sosialnya, perkembangan agama membutuhkan agen-agen yang menjadi semacam "penyalur". Tentu, agen-agen itu dipandang mempunyai kredibelitas untuk berbicara dan menyampaikan pesan-pesan agama. Pandangan yang kedua ini berasumsi bahwa mati dan berkembangnya sebuah agama sangat ditentukan apakah para "penyalur" dan "agen-agen" itu memasarkan agamanya atau tidak. Memang Tuhan tidak butuh "pembantu" untuk menunjukkan kuasanya, namun keberadaan tokohtokoh yang dianggap "merepresentasi" kekuasaan Tuhan melalui agama justru bisa menjadi semacam jalan penerang untuk mengarahkan orang pada jalan kebenaran.

Dalam kaitan ini, penulis berpandangan bahwa tidak mungkin otoritas hilang sama sekali dalam agama. Kehadiran agama tidak mungkin bisa dikenali tanpa kehadiran manusia. Kalau memang otoritas keagamaan tidak mungkin bisa dinafikan, pertanyaan berikutnya siapa yang mempunyai otoritas agama itu? Siapa yang memberi mandat? Untuk kepentingan apa adanya otoritas itu? Apakah otoritas agama bersifat temporer ataukah bersifat abadi? Dan sederet pertanyaan lainnya.

Tulisan ini tentu tidak berpretensi untuk menjawab sumua masalah tersebut. Tulisan ini lebih tepat diposisikan sebagai upaya untuk menyelami persoalan otoritas dalam Islam. Dalam kaitan ini, ada persoalan teoritik yang penting diangkat untuk memahami konstelasi teoritiknya. Di samping itu, 
persoalan historis juga penting diangkat untuk memahami bagaimana persoalan otoritas agama dalam Islam diperebutkan. Di sini kita akan bertemu, tumpang tindih antara otoritas agama dan otoritas politik. Tesis utama yang ingin diangkat dalam tulisan ini adalah bahwa otoritas agama bukanlah sesuatu yang berdiri sendiri. Karena sejarah agama tidak bisa dilepaskan dari politik, maka otoritas agama seringkali berkelindan dengan otoritas politik. Meski demikian, otoritas agama bukanlah konsep yang statis. Dalam perjalananya, otoritas agama sangat dinamis. Berbagai level otoritas agama dan hubungan antar berbagai level otoritas merupakan bagian dari dinamika tersebut.

Untuk memahami lebih jauh konsep otoritas, kita tidak bisa meninggalkan konsep Weber tentang tiga tipe kekuasaan: tradisional, rasional-legal, dan kharismatik. Tipe-tipe Weber tersebut dikaitkan dengan bentuk-bentuk aksi sosial dan hubungan-hubungan sosial yang menjadi ciri khas berbagai kelompok masyarakat. Memang tipologi yang dirumuskan Weber diletakkan dalam konteks kepemimpinan (politik). Namun, karena kepemimpinan tidak dapat dilepaskan dari otoritas, maka tipologi ini juga bisa kita adaptasi dalam melihat otoritas keagamaan.

Hal pertama yang harus dijelaskan dengan pengertian terminologi Weber adalah persoalan legitime herrschaf yang biasa diterjemahkan sebagai "kekuasaan" atau "dominasi yang absah". Herrschaf yang dimaksud Weber mengacu pada kemampuan seseorang untuk menegakkan kesetiaan kelompok. Bagi Weber, kriteria setiap hubungan yang melibatkan herrschaf adalah suatu bentuk penundukan diri secara sukarela. Faktor penting yang menopang stabilitas herrschaf adalah kepercayaan terhadap legitimasi. Tetapi konsep legitime herrschaf juga mencakup kemampuan memaksakan disiplin dan penggunaan sanksi-sanksi yang memaksa. ${ }^{1}$

Kategori Weber tersebut merupakan bentuk abstraksi, bukan diskripsi, realitas konkret. Namun, karena kharisma pada dasarnya merupakan fenomena spesifik dan terkadang mempengaruhi fenomena sosial yang sudah mapan, maka dua jenis kekuasaan yang absah adalah kekuasaan yang bersifat tradisional dan rasional-legal.

${ }^{1}$ April Carter, Otoritas dan Demokrasi, (Jakarta: Rajawali Press, 1979), h. 54-56. 
Kekuasaan tradisional, menurut Weber, berada dalam tata sosial yang bersandar pada kebiasaan-kebiasaan lama dimana status dan hak pemimpin ditentukan adat kebiasaan. Kekuasaan tradisional memerlukan adanya unsur-unsur kesetiaan pribadi (personal attachment) yang menghubungkan "tuan" dan "hambanya". Aturan-aturan yang menghubungkan mereka biasanya tidak tertulis, namun masing-masing saling memahami tentang posisi dan apa yang harus dilakukan.

Dalam tipe kekuasaan legal-rasional semua peraturan ditulis dengan jelas yang disepakati melalui proses tertentu dan diundangkan dengan tegas. Batas-batas kewenangan pihak-pihak yang terlibat ditentukan aturan main yang disepakati bersama. Kepatuhan tidak ditujukan kepada pribadi para pejabat, melainkan kepada lembaga yang bersifat impersonal. Model tata sosial yang bersifat legal-rasional yang paling murni adalah organisasi birokrasi yang mencerminkan adanya hirarki dan peraturan yang tegas yang mengendalikan pemangku jabatan di semua tingkatan. Orang-orang yang diseleksi untuk menduduki pos tertentu harus memenuhi kriteria kompetensi yang dibutuhkan. ${ }^{2}$

\section{B. Otoritas dan Kedaulatan Tuhan}

\section{Problem Otoritas Islam}

Beranjak dari paparan di atas, otoritas dalam Islam, pertama-tama harus dilihat sebagai fenomena sosiologis. Artinya, persoalan otoritas agama merupakan konstruksi sosial, bukan konstruksi teologis. Atau setidaknya, persoalan otoritas dalam Islam merupakan bentuk hubungan saling mempengaruhi antara konstruksi keyakinan keagamaan dengan realitas sosial.

Hal ini penting karena secara normatif-teologis, Islam tidak mengenal lembaga rahib (kerahiban) sebagaimana dalam Yahudi (lā rahbaniyata fi 'lIslām), maupun ke-Paus-an sebagaimana dalam Katolik yang mengontrol kehidupan agama, termasuk tafsir atas ajaran agama. Karena Islam tidak mengenal lembaga kerahiban, maka agama dalam Islam pada dasarnya adalah urusan yang sangat pribadi. Setiap pemeluk Islam diberi hak dan ruang untuk menghayati dan menafsirkan ajaran agamanya. Tidak ada orang

${ }^{2}$ Ibid, h. 56. 
atau kelompok yang bisa mengontrol atau menganggap penfasiran keagamaannya paling benar. Tidak ada "tafsir resmi" yang bisa mengontrol dan "membunuh" penafsiran lain.

Nah, untuk menghindari kekacauan dalam beragama, Islam mengenal konsep ijmā', sebuah konsep yang dibuat para ahli ușūl al-fiqh untuk menyelesaikan berbagai persoalan yang tidak ada landasan hukumnya secara pasti. Meski demikian, ijma $\bar{a}^{\prime}$ bukanlah konsep tunggal ${ }^{3}$ yang mengikat secara pasti kepada umat Islam. Sebagai produk ijtihad fiqhiyyah, produk ijmä' tetaplah hanya mengikat bagi orang yang mau mengikuti (mulzim bi nafsihi), tidak bisa dipaksakan kepada semua umat Islam.

Persoalan otoritas, terutama otoritas keagamaan, menjadi arena kontestasi berbagai kelompok-kelompok keagamaan. Dengan menggenggam otoritas, tidak jarang tindakan-tindakan otoriter dipamerkan dengan menghakimi kelompok lain yang dianggap melenceng dari rel keagamaan yang dianggap mapan. Bukan hanya soal penghakiman "aliran sesat", otoritas juga sering digunakan untuk mengontrol pemeluk agama lain. Mengontrol di sini dimaksudkan untuk mengendalikan perilaku pemeluk agama lain yang dikhawatirkan mengancam agama pemilik otoritas itu. Dengan memegang otoritas, Tuhan seolah bersemayam dalam diri orang itu. Ucapan dan tindakannya dianggap mewakili ucapan dan tindakan Tuhan. Akibatnya, melawan ucapan dan tindakan pemegang otoritas dianggap sama dengan melawan ucapan dan tindakan Tuhan. Pada titik ekstrem ini, otoritas agama akan mengancam keragaman dalam kehidupan agama, baik keragaman pemahaman agama maupun keragaman ekspresi keagamaan.

Dalam kaitan ini, untuk memahami aspek teoritik persoalan otoritas keagamaan, ada baiknya dikemukakan pendapat Khaled Abou el-Fadl, seorang ilmuwan kelahiran Kuwait yang kini menjadi Guru Hukum Islam di Fakultas Hukum UCLA Amerika Serikat. Khaled Abou el-Fadl ${ }^{4}$ membedakan dua jenis

\footnotetext{
3 Dalam disiplin ușūl al-fiqh, ada beragam defini tentang ijmā'. Ada yang menekankan ïmma ${ }^{\prime}$ sebagai kesepakan semua mujtahid pada suatu masalah yang tidak ada ketentuan hukumnya secara pasti sepeninggal Nabi Muhammad, ada yang menekankan sebagai kesepakatan sebagian mujtahid, ada yang mendefinisikan sebagai kesepakatan ahl al-halli wa 'l-aqdi, bahkan al-Ghazali mendefinisikan sebagai kesepakatan umat Muhammad, bukan hanya mujtahid. Lebih jauh lihat Abd alWahhab Khallaf, Ilmu Ușūl al-Fiqhi, (Kairo: Maktabah al-Da'wah al-Islāmiyyah, 1990), h. 45-52.

4 Khaled Abou el-Fadl, Atas Nama Tuhan, dari Fikih Otoriter ke Fikih Otoritatif, (Jakarta: Serambi, 2004), h. 37.
} 
sifat otoritas, yaitu otoritas yang bersifat koersif dan otoritas yang bersifat persuasif. Otoritas koersif merupakan kemampuan untuk mengarahkan perilaku orang lain dengan cara membujuk, mengambil keuntungan, mengancam, atau menghukum. Otoritas jenis ini sifatnya memaksa orang lain agar tunduk pada pikiran dan kehendaknya. Otoritas koersif ini biasanya terkait dengan kekuasaan politik dengan segala aparaturnya memiliki kekuatan untuk memaksa dan menghukum.

Sedang otoritas persuasif merupakan kemampuan untuk mengarahkan keyakinan dan perilaku orang lain atas dasar kepercayaan. Karena itu, otoritas persuasif melibatkan kekuasaan yang bersifat normatif yang berasal dari dalam diri orang itu. Otoritas jenis ini biasanya dikaitkan dengan pengetahuan seseorang, kharisma dan sejenisnya.

Dua jenis sifat otoritas ini terkait dengan pembedaan dua istilah berikutnya yang diambil Abou el-Fadl dari Richard Friedman dalam tulisan berjudul "On Concept of Authority in Political Philosophy,"5 yaitu: "memangku otoritas" (being in authority) dan "memegang otoritas" (being an authority). Memangku otoritas artinya menduduki jabatan resmi atau struktural yang memberi kewenangan untuk mengeluarkan perintah dan arahan. Pemangku otoritas dipatuhi karena dia mempunyai daya paksa. Dalam kasus ini tidak dikenal adanya ketundukan personal, karena seseorang bisa saja berbeda pendapat dengan pemangku otoritas, namun ia tidak mempunyai pilihan lain kecuali harus mengikuti kehendak pemangku otoritas. Dengan demikian, keterikatan seseorang pemangku otoritas lebih disebabkan adanya kekuatan yang memaksa dia harus tunduk.

Sedangkan ketaatan kepada "pemegang otoritas" melibatkan semangat yang berbeda. Di sini orang dengan penuh kesadaran meninggalkan pendapat pribadinya karena tunduk pada pemegang otoritas yang dipandang memiliki pengetahuan, kebijaksanaan, atau pemahaman yang lebih baik. Dengan demikian, ketundukan orang kepada pemegang otoritas adalah ketundukan dan ketaatan sukarela. Ketundukan itu didasarkan pada kesadaran individu untuk mengikuti pendapat seseorang.

5 Tulisan Friedman tersebut dimuat dalam R. Flatham (ed.), Concept in Social and Political Philosophy, (New York: McMilaan, 1973). 
Pertanyaannya adalah apakah hubungan-hubungan kekuasaan itu harus mengacu pada hubungan tuan dan hamba; apakah penerimaan terhadap kekuasaan menghendaki adanya ketundukan buta; apakah kesetiaan pada kekuasaan harus berarti yakin bahwa perintah merupakan hak yang instrinsik.

Richard Friedman sebagaimana disinggung di atas, mempunyai dua penafsiran untuk membedakan kekuasaan. Dia berpendapat, kekuasaan yang berasal dari ilmu pengetahuan yang tinggi pada dasarnya berbeda total dengan jenis kekuasaan yang diperoleh karena menduduki jabatan politis tertentu. Mengakui seseorang sebagai penguasa berarti mengakui superioritas intrinsik, memberikan kesetiaan yang tidak diragukan lagi dan meyakini bahwa apa yang dikatakan penguasa adalah benar. Namun hal ini tidak berarti semua perintahnya adalah kebenaran yang perlu ditaati. Di sana tetap diperlukan adanya kesadaran kritis meskipun kepatuhan juga diperlukan. Kekuasaan ilmu pengetahuan persandar pada tradisi, sedangkan kekuasaan jabatan didasarkan pada pengakuan diperlukannya pemangku jabatan, diterimanya aturan main serta ketentuan-ketentuan lainnya. ${ }^{6}$

April Carter memberi kritik terhadap karakterisasi Friedman tentang kekuasaan yang dianggap melapiskan satu perbedaan dasar, yaitu kontras antara kekuasaan yang diperoleh dari konsensus atas berbagai keyakinan bersama, yang merupakan tipikal masyarakat tradisional, dan kekuasaan yang diperoleh dari kerangka umum ketentuan-ketentuan yang diterima, yang merupakan ciri masyarakat rasional. Hal yang perlu ditegaskan adalah perbedaan antara keberadaan kekuasaan dan berada di dalam kekuasaan. Membedakan dua hal itu akan membingungkan, terutama tentang apa yang dimaksud dengan keberadaan kekuasaan dengan memasukkan berbagai asosiasi masyarakat tradisional yang herarkis dan otoritarian ke dalam citra kekuasaan yang bersandar pada pengetahuan khusus atau kebijaksanaan.

Ada beberapa konteks dimana pengertian keberadaan kekuasaan mempunyai konotasi, misalnya jika kekuasaan dianggap sebagai takdir ilahi. Tetapi umumnya dapat ditegaskan bahwa jenis pengetahuan yang dihubungkan dengan pengetahuan khusus secara inheren tidak bersifat hierarkis dan

${ }^{6}$ April Carter, Otoritas dan Demokrasi, h. 29-30. 
mencerminkan adanya kebebasan untuk mempertanyakan atau menghujat kepatuhan.

Memang kekuasaan profesional kaum cendekiawan terhadap bawahannya dapat diterapkan dalam suasana otoritarian, tetapi ia tidak harus menuntut kepatuhan mutlak dari setiap bawahan. Para ahli selalu berada dalam posisi memberi pelayanan pada kliennya. Kaum awam tidak harus selalu menerima kekuasaan profesional tanpa mempertimbangkan urgensinya, tetapi selalu terbuka peluang untuk memperoleh alternatif pendapat profesional. Wewenang untuk memberi pandangan atas suatu masalah tidak mengandung pengertian adanya penerimaan.

Keberatan kedua April Carter atas tesis Friedman ialah bahwa suatu usaha untuk membedakan secara tepat antara pengertian "kekuasaan" dengan "berada di dalam kekuasaan" telah mengabaikan masalah sejauhmana terdapat saling keterkaitan antara keduanya. Friedman membatasi argumentasinya hanya sampai kekuasaan pejabat politik. Tetapi jelas tidak mungkin membatasi konsep "berada dalam kekuasaan" hanya sampai pada tingkat pemerintahan saja, karena ia juga dapat diterapkan pada organisasi sosial dalam berbagai skala. ${ }^{7}$

Dari dua jenis otoritas yang dikemukakan Friedman tersebut, Abou elFadl menambahkan satu jenis lagi, yaitu "otoritas koersif". Jenis otoritas ini sebenarnya difungsikan untuk melengkapi istilah "memangku otoritas" yang dikemukakan Friedman. Abou el-Fadl menggunakan istilah "otoritas koersif" karena jabatan resmi dan kekuasaan struktural yang dimiliki seseorang pemangku otoritas tidak selalu bisa diketahui dengan jelas. ${ }^{8}$ Dia mencontohkan pejabat di negara-negara berkembang sebagai pemangku otoritas ditaati karena dia mempunyai kekuasaan yang bisa memaksa, tapi pejabat yang lain diabaikan dan dilangkahi karena ada cara lain yang bisa ditempuh meskipun dengan cara-cara yang ilegal. Dari perspektif ini kita bisa memahami, bagaimana perkawinan antara otoritas keagamaan dan otoritas politik yang tidak dikendalikan dengan baik bisa menjadi ancaman serius.

Sampai di sini penulis ingin memasuki perdebatan yang lebih subtil soal pemegang otoritas dalam Islam. Persoalan ini penting untuk diangkat karena

\footnotetext{
${ }^{7}$ Baca April Carter, Otoritas dan Demokrasi, h. 30-35.

8 Khaled Abou el-Fadl, Atas Nama Tuhan, h. 42.
} 
pangkal tolak perdebatan modern, terutama menyangkut sejumlah konsepkonsep politik dalam Islam, seperti soal hubungan agama dan negara beranjak dari perdebatan ini.

Dalam Islam diyakini, Allah, Nabi Muhammad dan al-Qur'an merupakan otoritas tertinggi. Ketiganya dipandang sebagai pemegang otoritas yang sebenarnya. Cara pandang demikian disepakati umat Islam, namun kesepakatan demikian perlu penjelasan lebih lanjut untuk menghindari kesalahpahaman. Penjelasan yang baik mengenai hal ini dapat ditelusuri dari sejarah tentang bagaimana umat Islam menghayati doktrin tersebut. Umat Islam telah menyaksikan kenyataan sejarah pada masa kepemimpinan Khalifah Utsman bin Affan (23-35 H/644-656 M) yang dituduh gagal menjalankan sistem pemerintahan dengan sistem shürā dan dituduh telah memerintah dengan mengikuti hawa nafsunya, bukan dengan hukum Allah. Pembangkangan kepada Utsman bin Affan bermuara pada pembunuhan atas dirinya dan pemberontakan yang dikenal dengan fitnah al-kubrā.

Ali bin Abi Thalib (memerintah 35-40 H/656-661 M) menghadapi tiga kelompok yang memberontak: kelompok Suriah yang dipimpin keponakan Utsman, Muawiyah (w. 60 H/680 M); kelompok Quraisy yang dipimpin istri Nabi Muhammad, A'isyah binti Abu Bakar (w. 58 H/678 M); dan pemberontakan kelompok puritan yang dikenal sebagai qurrā' (para penghafal alQur'an) yang kemudian dikenal sebagai Khawarij.

Argumentasi Khawarij terkait dengan doktrin keagamaan menarik untuk dikaji untuk melihat bagaimana mereka memahami otoritas keagamaan. Pada mulanya mereka pendukung Ali bin Abi Thalib sebagai khalifah yang berjuang melawan pemberontakan kelompok A'isyah dalam perang Unta (35 H/656 M). mereka juga berjuang bersama Ali dalam perang Shiffin $(37 \mathrm{H} / 657$ M) melawan Mu'awiyah. Namun ketika Ali sepakat mengakhiri konflik dengan Mu'awiyah melalui arbitrase, kelompok Khawarij memisahkan diri dan akhirnya membunuh Ali bin Abi Thalib. Jargon yang diusung Khawarij adalah "kedaulatan hanya milik Allah" (al-ḥākimiyyah lillāh). Dengan menerima arbitrase Ali dianggap telah berkhianat kepada Allah, karena telah menerima keputusan manusia, bukan keputusan Allah. Kedaulatan, menurut Khawarij, hanyalah milik Allah, sehingga hukum Allah yang termuat dalam al-Qur'an harus dijalankan.

Dalam sebuah riwayat diceritakan, kelompok Khawarij mengklaim bahwa "semua hukum hanyalah milik Allah" (lā ḥukma illā lillāh). Menjawab 
pernyataan kelompok Khawarij tersebut Ali mengatakan, pernyataan tersebut memang benar, tapi apa yang mereka maksud dengan pernyataan itu keliru. Memang, lanjut Ali bin Abi Thalib, semua hukum milik Allah, namun mereka tidak bisa mengklaim pemerintahan ini juga milik Allah. Yang benar, menurut Ali, kita tidak bisa lari dari kenyataan bahwa manusia mau tidak mau harus mengandalkan pemerintah karena dengan itu pajak dikumpulkan, musuh bisa diusir, jalan-jalan dilindungi dan hak-hak orang yang lemah diambil dari orang yang kuat.

Dalam riwayat lain disebutkan, beberapa pengikut Khawarij menyatakan: "Ali telah tunduk pada keputusan manusia, padahal keputusan hanyalah milik Tuhan". Dalam menjawab tuduhan tersebut Ali mengumpulkan sejumlah orang dengan membawa mushaf kemudian berkata: "Wahai alQur'an, berbicaralah pada manusia". Orang-orang berada di sekitar Ali gusar sambil berkata: "Ali, apa katamu! Apakah engkau mengejek kami? Al-Qur'an hanyalah lembaran-lembaran kertas tinta, hanya manusia yang berbicara atas nama al-Qur'an". Ketika itu, Ali kemudian berkata: "al-Qur'an ditulis dengan goresan diantara dua sampul. Ia tidak bisa bicara. Al-Qur'an butuh penafsir, dan penafsir itu adalah manusia". ${ }^{9}$

Dari riwayat tersebut menunjukkan bahwa implikasi persoalan makna kedaulatan Tuhan sudah muncul sejak masa-masa awal Islam yang kemudian membentuk kategori diskursus tersendiri. Dari sini, muncul pula diskursus lain yang yang mempermasalahkan kedaulatan Tuhan. Dalam sebuah riwayat yang dinisbatkan kepada Abu Bakar ibn al-'Arabi (w. 543 H/1148 M) dijelaskan adanya struktur narasi dan bentuk skeptisisme tentang kedaulatan Tuhan. Diriwayatkan, seorang wazir mengkritik pendekatan kaum puritan tekstualis dalam menafsirkan hukum dengan mengatakan:

Klaim mereka bahwa yang menjadi patokan (dalam menafsirkan hukum) adalah wahyu Tuhan sepenuhnya benar, tetapi saya berpendapat: "tantangan sebenarnya adalah memahami apa yang sebenarnya dikatakan Tuhan". Klaim mereka bahwa kedaulatan sepenuhnya milik Tuhan (lā ḥukma illā lilläh) tidak dapat kita terima. Pelimpahan kedaulatan-Nya ke tangan manusia dalam menafsirkan firman Tuhan adalah bagian dari hukum Tuhan. Itulah sebabnya mengapa Nabi Muhammad bersabda: "Jika kamu mengepung

${ }^{9}$ Khaled Abou el-Fadl, Atas Nama Tuhan, h. 46-47. 
benteng musuh, janganlah kalian mengijinkan penghuni benteng itu menyerah berdasarkan syarat-syarat yang terdapat dalam hukum Tuhan, karena kalian (dan mereka) tidak tahu apa sebenarnya hukum Tuhan itu. Perintahkan mereka untuk menyerah berdasarkan hukum (persyaratan) kalian". ${ }^{10}$

Pernyataan tersebut secara jelas menunjukkan betapa kedaulatan Tuhan bukanlah entitas yang berdiri sendiri. Pernyataan "kedaulatan hanyalah milik Tuhan" sebagai pernyataan normatif sering dibelokkan dalam sebuah diskursus politik. Hal ini tidak terlepas dari hasrat sebagian kalangan yang ingin menjadikan Islam tidak sekedar sebagai agama, tapi juga sebagai alat politik.11 Pernyataan normatif tersebut sebenarnya menyerukan keadilan, kejujuran, kesalehan atau nilai-nilai normatif yang bersifat abstrak. Namun, karena kedaulatan Tuhan harus dilimpahkan kepada manusia yang menafsirkan dan melaksanakan kedaulatan, maka jargon tersebut sering digunakan sebagai propaganda politik untuk tujuan kekuasaan, bukan Tuhan.

Meski demikian, kita harus menerima kenyataan bahwa perdebatan soal kedaulatan Tuhan ini tidak semata-mata terkait dengan persoalan sosial ekonomi dan konflik politik dalam Islam, karena dalam al-Qur'an sendiri ada teks yang secara harfiah menunjukkan adanya kedaulatan Tuhan dan kewajiban untuk mentaati Tuhan.12 Al-Qur'an memerintahkan pemeluk Islam untuk melaksanakan perintah Allah, dan membedakannya dengan mengikuti nafsu manusia. Allah memerintahkan nabi-nabi untuk mengadili manusia berdasar hukum Tuhan dan dilarang tunduk pada hawa nafsu. ${ }^{13}$ Al-Qur'an juga memerintahkan untuk menyelesaikan perselisihan dengan merujuk pada Tuhan dan nabi-Nya. Mereka yang menolak menyelesaikan perselisihan dengan keputusan ( $q a d \hat{a}^{\bar{a}}$ ) Tuhan dan nabi-Nya tidak dipandang sebagai orang Islam sejati. ${ }^{14}$

${ }^{10}$ Khaled Abou el-Fadl, Atas Nama Tuhan, h. 48, yang dikutip dari kitab Siyār al-'Alam, karya al-Dzahabi, Jil. 18, h. 190.

${ }^{11}$ Muhammad Said al-Asymawi, al-Islāmm al-Siyāsi, (Kairo: Sina Linnasyr, 1978), h. 15.

12 Al-Qur'an misalnya menyatakan: "Keputusan itu hanyalah milik Allah. Dia sudah memerintahkan agar kamu tidak menyembah selain Dia. Itulah agama yang benar, tetapi kebanyakan manusia tidak mengetahui" (QS. Yusuf [12]: 40. di bagian lain juga disebutkan: "Dan Ya'kub berkata .... Keputusan menetapkan (sesuatu) hanyalah milik Allah. Kepada-Nya aku bertawakkal dan hanya kepada-Nya saja orang-orang menyerahkan diri” (QS. Yusuf [12]: 67. Lihat juga QS. al-An'am [6]: 57; Yusus [12]: 40.

${ }^{13}$ QS. al-Maidah [5]: 49; Shad [38]: 26. 10.

${ }^{14}$ QS. Ali Imran [3]: 23; al-Ma'idah [5]: 44-45, 47; al-Nur [24]: 48; al-Nisa' [4]: 65; al-Syara [42]: 
Penulis tidak ingin memasuki wilayah yang lebih dalam terkait dengan penafsiran ayat-ayat tersebut, tapi sekedar ingin menunjukkan bagaimana kompleksitas persoalan dan kerumitan yang dihadapi dalam menjelaskan problem ini. Sejarah perdebatan Ali bin Abi Thalib dengan kelompok Khawarij terkait dengan peristiwa taḥkìm merupakan contoh bagaimana kerumitan itu dihadapi generasi Islam awal. Kedua belah pihak, Ali dan Khawarij, menganut konsep yang sama sekali berbeda. Menurut Khawarij, hukum Allah bisa ditentukan secara akurat, baik menyangkut makna (istinbāțiy) maupun penerapannya (tațbiqiy). Namun, Ali bin Abi Thalib memandang bahwa hukum Allah tidak bisa ditentukan dengan mudah, sehingga peran manusia sangat besar.

Perdebatan Ali dan Khawarij itu juga menyisakan problem soal posisi "penguasa". Apakah penguasa bisa mewakili Tuhan atau tidak. Dari kasus tahkim, posisi Khawarij bisa ditafsirkan sebagai bentuk tidak mengakui hak perwakilan penguasa atau perundingan. Konsep perwakilan lebih bersifat individual dan personal, tanpa mempertimbangkan posisi penguasa sebagai penengah perundingan.

Di samping ayat-ayat yang bisa ditafsirkan memberi bobot pada otoritas dan kedaulatan Tuhan, beberapa ayat al-Qur'an juga memberi peran besar kepada manusia. Hal ini terkait dengan kenyataan, Allah menciptakan manusia sebagai khaliffah-Nya. Khalïfah bisa berarti pewaris, wakil atau pelaksana. Al-Qur'an misalnya menyatakan: "Dialah yang menjadikan kamu khaliffah di muka bumi. Barang siapa ingkar kepada Tuhan, keingkarannya itu akan menimpa dirinya sendiri". ${ }^{15}$ Kedaulatan memang milik Tuhan, tapi dengan ayat ini dipahami kedaulatan ini hanya dapat dilaksanakan manusia yang bertindak atas nama Tuhan. Karena sebagai pelaksana, maka manusia tidak bisa sepenuhnya bisa bebas karena terikat dengan berbagai perangkat instruksi yang dibuat Tuhan. Mereka tidak boleh berbuat melampaui mandat yang diberikan.

Di samping itu, al-Qur'an juga seringkali menyebut asas keadilan ('adl) dan keseimbangan (qist) sebagai cita-cita tertinggi yang ingin ditegakkan. Hal itulah yang juga harus dijunjung tinggi manusia sebagai khaliffah-Nya. Keadilan dan keseimbangan di sini lebih bermakna substantif daripada

15 QS. al-Fathr [35]: 39. 
prosedural. Hal itu memperkuat pemahaman bahwa manusia mempunyai ruang gerak yang cukup luas untuk melakukan penalaran kreatif.

Faktor lain dalam al-Qur'an yang digambarkan mempengaruhi wewenang adalah gagasan tentang penangguhan keputusan. Al-Qur'an memberi peluang, tidak semua perbedaan pendapat dapat diselesaikan di dunia. Allah yang akan menjadi "hakim" atas apa yang diperselisihkan di dunia. Bukan sekarang, tapi di akhirat kelak. ${ }^{16}$ Dengan demikian gagasan tentang "keputusan tunda" dan al-Qur'an diturunkan untuk menyelesaikan semua persoalan sama-sama diakomodasi dalam al-Qur'an. Al-Qur'an memiliki kemampuan untuk menyelesaikan perselisihan dan menunjukkan jalan lurus. Namun, dalam al-Qur'an juga ada pengakuan terhadap perselisihan yang keputusannya akan ditentukan Allah sendiri. Artinya, manusia tidak bisa sepenuhnya menempatkan diri sebagai pemegang otoritas ke-Tuhan-an.

Gagasan tentang penangguhan keputusan ini pada akhirnya memainkan peranan penting dalam perkembangan hukum Islam, termasuk munculnya keragaman dalam hukum Islam. Salah satu sekte dalam Islam yang mengusung gagasan ini adalah Murji'ah, yang menyatakan bahwa berbagai masalah yang diperselisihkan umat Islam keputusannya harus ditangguhkan hingga hari kiamat. Tuhan yang mempunyai otoritas untuk menyelesaikan, bukan manusia. Kelompok ini pada awalnya muncul sebagai reaksi terhadap gerakan Khawarij yang puritan dan perang saudara antara Ali dan lawanlawannya. Doktrin Murji'ah (dikenal dengan doktrin irja') menjadi tipikal gerakan politik untuk menghindari konflik politik dan penganut relativisme moral.

Namun, Murji'ah sebagai sebuah sekte tidak berkembang. Hal ini antara lain disebabkan, dalam banyak kasus soal keagamaan manusia membutuhkan kepastian untuk menentukan kebenaran. Kepastian kebenaran itu, dalam pandangan banyak kalangan hanya bisa ditemukan dalam agama. Kalau agama menunda penyelesaian seluruh masalah sampai nanti menunggu hari kiamat maka agama menjadi tidak fungsional. Karena itulah, sekte ini segera tergantikan oleh mazhab lain yang lebih kritis, yaitu Mu'tazilah dan Asy'ariyah. Meski pada awalnya dua aliran ini lebih sebagai sekte teologi, namun pengaruhnya terhadap hukum Islam tidak bisa diabai-

${ }^{16}$ QS. Ali Imran [3]: 55; al-Zumar [39]: 3, 46; al-Ma'idah [5]: 48, dan sebagainya. 
kan. ${ }^{17}$ Kedua aliran tersebut lebih "bertanggung jawab" untuk menyelesaikan berbagai persoalan keagamaan dengan tidak menunda-nunda sampai nanti di akhirat dengan perspektifnya masing-masing.

Meski begitu, penulis merasa bahwa doktrin irja'-nya Murji'ah mempunyai manfaat, setidaknya untuk menjadikan orang tidak memaksakan keinginannya atas masalah yang diperselisihkan. Hal ini bisa menjadi semacam katup untuk keluar dari masalah krusial yang sulit diselesaikan. Kesadaran dan pengakuan adanya hukum yang tertunda, secara tidak langsung menyiratkan adanya sikap rendah hati pada pihak lain yang berbeda dengan kita. Namun, jika semua hal harus ditunda penyelesaiannya, maka agama menjadi tidak mempunyai makna. Oleh karena itu, doktrin irja' ini tepat digunakan pada masalah-masalah yang bisa memicu konflik karena ketidakmampuan manusia mencari titik-titik perdamaian atas konfliknya sendiri. Menunda penyelesaian sebagaimana diisyarakatkan dalam sejumlah ayat alQur'an bisa menghidarkan orang dari keterjebakan otoritarianisme dalam beragama.

Sikap otoriter dalam beragama inilah yang penting untuk dihindari. Doktrin teologi maupun hukum Islam yang semestinya memberi ruang bagi umat Islam untuk berimprovisasi melakukan pembaruan dan revitalisasi, seringkali tertutup dengan sikap otoriter. Kecenderungan otoriter ini telah mengebiri tradisi hukum Islam yang tidak sekedar mementingkan hasil, tapi lebih pada proses. Dengan kata lain, kecenderungan otoriter semacam ini memanfaatkan efek tradisi hukum Islam yang berpengaruh untuk menempatkannya sebagai sesuatu yang memiliki otoritas dan relevansi.

\section{Otoritas Agama versus Otoritas Politik}

Pertanyaan yang kemudian muncul adalah bagaimana kita harus meletakkan otoritas keagamaan yang berdimensi ilahiyah, transenden dan mutlak dalam bingkai otoritas politik yang tempores, profan dan relatif. Pertanyaan ini telah sekian lama mengganggu pikiran para sarjana untuk membuat rumusan-rumusan yang memungkinkan. Hal paling krusial dalam persoalan ini bagaimana membendung upaya menjadikan agama sebagai tameng politik kekuasaan di satu pihak, dan menjadikan agama sebagai legitimasi tindakan otoriter di pihak lain.

${ }^{17}$ Khaled Abou el-Fadl, Atas Nama Tuhan..., h. 56-57. 
Dalam konteks Islam, hal ini tidak mudah dicarikan jalan keluarnya. Jika sekularisme dipandang sebagai jalan keluar yang paling memungkinkan untuk membendung arus otoritarianisme agama melalui institusi negara, konsep ini tidak dengan mudah diterima umat Islam. Ada semacam gugatan misalnya, mengapa kalau hukum yang diadopsi dari barat diimplementasikan melalui negara tidak dipermasalahkan, tapi kalau hukum Islam dipersoalkan. Demikian juga dengan pertanyaan, mengapa Islam sebagai legitimasi politik dipersoalkan, padahal Islam tidak bisa dipisahkan dari kehidupan politik. Bahkan, sejarah Islam adalah sejarah politik. Pertanyaan gugatan tersebut muncul antara lain disebabkan karena komplikasi dari problem keterkaitan antara otoritas agama dan otoritas politik.

Berbeda dengan agama-agama yang lain, Islam sejak masa awal pendiriannya sering dipahami sebagai negara itu sendiri. Identitas agama dan pemerintah melekat tidak terhapuskan pada imajinasi dan kesadaran umat Islam, sejak dari teks suci, sejarah dan pengalaman. ${ }^{18}$ Bagi umat Islam, agama secara tradisional telah menjadi landasan, pusat identitas dan kesetiaan. Karena itu, tidak mengherankan jika gerakan-gerakan sosial dan politik yang paling signifikan dalam sejarah Islam modern telah menempatkan Islam sebagai kekuatan pendorong dan pemersatu.

Hal yang paling mengkhawatirkan adalah terjadinya "perselingkuhan" dua otoritas. ${ }^{19}$ Perselingkuhan dua otoritas itu setidaknya akan membawa dua dampak. Pertama, akan terjadi proses dimana urusan politik yang mestinya bersifat sekuler dan temporer bisa berubah statusnya menjadi urusan ukhrawi dan sakral. Karena itu, apabila seseorang melawan otoritas

18 P.J. Vatikiotis, Islam and the State, (London: Rouledge: 1987), p. 22-30. Lihat juga Abdullahi Ahmed al-Na'im, Dekonstruksi Syariah, (Yogyakarta: LkiS, 1994), h. 7. Lihat juga Dr. Muhammad Iqbal, Fiqh Siyasah: Kontekstualisasi Doktrin Politik Islam, (Jakarta: GMP, 2007), h. 31-43.

${ }_{19}$ Contoh yang paling fenomenal mengenai "perselingkuhan" dua otoritas ini adalah kasus Mihnah pada masa pemerintahan al-Makmun (198-218 H / 813-833 M) sampai masa khalifah alWatsiq (842-847 M). Pada masa ini Mu'tazilah mendominasi pemerintahan sehingga pemerintah mengeluarkan dekrit mihnah (inquisition). Mihnah adalah suatu kebijaksanaan yang dilakukan oleh khalifah al-Makmun tentang diberlakukannya pemeriksaan atau lebih tepatnya dikatakan pemaksaan kepada rakyatnya terhadap penerimaan doktrin al-Qur'an itu makhluk. Peristiwa ini dilaksanakan dengan menggunakan kekuatan politik, bahkan dengan kekerasan. Ulama yang menjadi korban dari peristiwa ini adalah Imam Ahmad bin Hanbal (164 H/780 M - 241 H/855 M yang disiksa karena tidak mau mengikuti doktrin teologi Mu'tazilah yang menjadi doktrin teologi pemerintah al-Makmun. Informasi lebih jauh tentang hal ini lihat Philip K. Hitti, History of the Arabs, (London: Macmillan Press LTD, 1974), p. 429-430. 
politik maka orang itu segera bisa dikatakan melawan otoritas agama sekaligus. Melawan hukum negara sama artinya melawan hukum agama. Cara pandang seperti ini sangat potensial digunakan para penguasa politik untuk menghabisi lawan-lawan politiknya dengan menggunakan isu dan jargon keagamaan.

Kedua, menyandarkan otoritas agama kepada kepada otoritas politik berarti menyandarkan sesuatu yang mutlak kepada yang relatif. Kesempurnaan yang mutlak seolah harus bersandar pada yang relatif. Hal ini sama dengan anggapan, agama tidak akan bisa tegak jika tidak ditegakkan melalui negara. Cara pandang demikian mengandung problem teologis, karena kebenaran ajaran Islam sebenarnya tidak terletak pada apakah ajaran itu diadopsi negara atau tidak, tapi terletak pada sejauh mana ajaran itu bisa mempengaruhi dan membentuk kesadaran masyarakat.

Hal yang paling krusial menyangkut hal ini adalah bagaimana Islam, terutama hukum publik (syariah) Islam berhadapan dengan konstitusionalisme dalam paham negara hukum. Hal ini problematik karena dalam sejarah Islam awal tidak mengenal konstitusionalisme sebagaimana hukum modern. ${ }^{20}$ Ketaatan umat Islam pada agama bukan karena agama ditegakkan melalui kekuasaan negara, tapi lebih karena keimanan yang mengikat mereka secara spiritual. Karena itu, dalam konteks negara modern seringkali muncul kesenjangan dalam alam pikir umat Islam antara ketundukan kepada hukum negara yang bersifat represif-temporer, dan hukum agama yang bersifat spiritual-ilahiyah.

Berangkat dari situasi tersebut, negara dalam teori politik Islam paling jauh bergerak dari teokrasi dan nomokrasi. Dalam negara teokrasi, penguasa memegang pemerintahan berdasar mandat dari Tuhan. Tuhan sebagai sum-

20 Negara Islam mengenal konstitusi baru pada abad ke-19. Negara yang kali pertama mengadakan konstitusi adalah kerajaan Utsmani pada 1876 yang ditandatangani Sultan Abdul Hamid. Konstitusi yang terdiri dari 19 bab 119 pasal itu banyak dipengaruhi Konstitusi Belgia 1831. Dalam konstitusi ini ditegaskan, Sultan Abdul Hamid adalah pemegang kekuasaan kekhalifahan Islam (Khilafet-i Kubrayyi Islamiyye) yang menjadi pelindung agama Islam. Namun konstitusi ini belum mengenal pemisahan trias politica. Peristiwa ini terkait dengan serangkaian peristiwa pembaruan hukum dimana pengaruh hukum Eropa begitu kuat terhadap hukum Islam. Pada periode ini diperkenalkan juga pembaruan hukum niaga 1850, hukum pidana 1858, hukum tata niaga 1879, hukum perdata 1880, hukum niaga kelautan yang semuanya mengikuti hukum model Eropa yang mengusahakan sebuah model perundangan yang komprehensif. Lihat Abdullahi Ahmed al-Naim, Islam dan Negara Sekuler, Menegosisikan Masa Depan Syariah, (Bandung: Mizan, 2008), h.35. Lihat juga Dr. Muhammad Iqbal, Fiqh Siyasah, h. 158. 
ber kekuasaan menunjuk sebagian manusia untuk menjadi penguasa atas manusia lainnya. Karena itu, penguasa tidak bertanggung jawab kepada rakyat tetapi kepada Tuhan.

Konsep nomokrasi sedikit bergerak dari teokrasi meski ujungnya teokrasi juga. Dalam negara nomokrasi, kepala negara menjalankan pemerintahan tidak berdasar mandat Tuhan, tetapi berdasar hukum-hukum syariat yang diturunkan Tuhan kepada manusia melalui rasul-Nya. Sejauh disebut secara tegas dalam syariat, maka penguasa tinggal melaksanakan saja apa yang disebut dalam syariat. Namun karena hukum syariat lebih banyak yang bersifat global, manusia diberi wewenang yang luas untuk berijtihad terhadap masalah-masalah yang belum diatur dalam syariat. ${ }^{21}$ Dari sini dapat dilihat, konsep nomokrasi pun sebenarnya lebih dekat pada teokrasi daripada demokrasi, karena nomokrasi masih tetap mengandaikan adanya hukum syariat yang ditegakkan melalui negara. Hal inilah yang oleh Ahmed al-Naim disebut sebagai "ilusi berbahaya" negara Islam yang bisa menjalankan syariah melalui kekuatan negara yang memaksa. ${ }^{22} \mathrm{Hal}$ ini sama berbahayanya dengan upaya menarik Islam dari kehidupan publik umatnya.

\section{Otoritas Islam di Indonesia: MUI?}

Sebagaimana Islam Sunni di banyak negara Islam, Indonesia sebenarnya tidak mengenal otoritas tunggal. Otoritas keislaman di Indonesia menyebar dalam berbagai lapisan, baik dalam lembaga-lembaga agama, lembaga negara, maupun tokoh-tokoh lokal. Lembaga-lembaga keagamaan seperti Nahdlatul Ulama (NU), Muhammadiyah, Persis mempunyai lembaga fatwa untuk memberi panduan kepada umatnya dalam berbagai soal agama. Demikian juga dengan Majelis Ulama Indonesia (MUI) melalui Komisi Fatwa secara reguler mengeluarkan sejumlah fatwa.

Adanya berbagai lembaga fatwa sebenarnya merupakan bukti adanya pluralisme pemahaman dan penafsiran Islam di Indonesia. Di antara lembaga-lembaga fatwa pendapatnya tidak bisa saling menafikan atau menghapuskan. Keragaman pendapat lembaga-lembaga fatwa tidak lebih sebagai keragaman pendapat hukum yang memberi ruang kepada masyarakat untuk

21 Dr. Muhammad Iqbal, Fiqh Siyasah, h. 202.

${ }^{22}$ Abdullahi Ahmed al-Naim, Islam dan Negara Sekuler, h. 21. 
memilih. Kebenaran sebuah fatwa hukum tidak semata-mata terletak pada akurasi dari sisi kesesuaian dengan dalil-dalil nash (manqū $l$ ), tapi sejauhmana fatwa tersebut bisa memberi panduan moral yang berkeadilan bagi masyarakat untuk menyelesaikan masalah yang dia hadapi. Karena itu, fatwa yang dari sisi manqūl benar, belum tentu dia menemukan relevansi untuk diikuti dalam kehidupan riil.

Adanya lembaga-lembaga fatwa tersebut merupakan bentuk pengakuan bahwa al-Qur'an dan Hadits tidak bisa "klik" secara langsung untuk menghukumi masalah-masalah tertentu. Perlu jalan bertahap, memutar, bahkan berliku-liku untuk memahami makna dalam nash (ma'qūl al-nāss) dengan metodologi yang bisa dipertanggungjawabkan. Fatwa-fatwa keagamaan semestinya menjadi sarana pendidikan bagi masyarakat untuk memahami ma'qūl al-nāṣ tersebut. Karena itulah, dalam disiplin ilmu uṣūl al-fiqh seseorang atau lembaga fatwa disebut sebagai kāshif al-ḥukmi (penyingkap/ penemu hukum), bukan munshi' al-h̆ukmi (penetap hukum).

Diantara lembaga-lembaga fatwa yang ada di Indonesia, MUI bisa dikatakan sebagai lembaga fatwa yang penting diamati. Bukan saja karena MUI dibentuk pemerintah orde baru, tapi karena belakangan ada upaya untuk menjadikan fatwa MUI menjadi bagian dari proses legislasi. Ada upaya agar fatwa MUI menjadi hukum positif. Di samping itu, beberapa fatwa MUI sering memicu kontroversi dan dijadikan legitimasi tindak kekerasan kelompok tertentu. MUI seolah menjadi pemegang otoritas keagamaan tertinggi di Indonesia.

Dalam kaitan ini, penulis merasa perlu untuk sedikit memberi gambaran tentang MUI. MUI merupakan organisasi keulamaan yang dibentuk pemerintah Orde Baru pada 28 Juni 1975. Namun pelantikan kepengurusan MUI baru dilakukan pada 27 Juli 1975. Pembentukan lembaga ini diawali dari suatu Konferensi para ulama di Jakarta yang diselenggarakan oleh Pusat Dakwah Islam dari tanggal 30 September hingga 4 Oktober 1970. dari konferensi itu diajukan suatu saran untuk memajukan kesatuan kaum Muslimin dalam kegiatan sosial mereka dengan membentuk sebuah majelis bagi para ulama Indonesia, yang akan diberi tugas untuk untuk memberi fatwa-fatwa. Campur tangan pemerintah dalam soal ini terlalu besar untuk diabaikan karena pusat dakwah itu sendiri telah dicetuskan atas gagasan $\mathrm{KH}$. Muhammad Dahlan, Menteri Agama pada saat itu.

Akan tetapi saran demikian tidak diperhatikan oleh para ulama selama 4 tahun. Baru pada tahun 1974, sewaktu pusat tersebut mengadakan lokakrya 
nasional bagi para juru dakwah Muslim Indonesia, disepakati bahwa pembentukan majelis ulama semacam itu harus diprakarsai pada tingkat daerah. Persetujuan ini tercapai setelah ada saran Presiden Soeharto sendiri, yang dalam pidato pembukaannya pada lokakarya tersebut menyarankan perlunya sebuah badan nasional bagi para ulama untuk mewakili kaum Muslimin.

Soeharto telah berkeras hati dalam hal ini sehingga pada tanggal $24 \mathrm{Mei}$ 1975, sewaktu menerima delegasi Dewan Masjid Indonesia, ia sekali lagi menekankan perlunya dibentuk Majelis Ulama Indonesia. Baru setelah itu Menteri Dalam Negeri Amir Mahmud menganjurkan semua gubernur untuk mulai membentuk majelis ulama tingkat daerah. Dalam waktu singkat, pada bulan yang sama, Mei 1975 majelis ulama daerah telah terbentuk di hampir semua dari 26 propinsi yang ada di tanah air. Pada masa Pemerintahan Soeharto, desakan untuk membentuk membentuk semacam majelis ulama nasional tampak mudah dan jelas, ketika pada tanggal 1 Juli 1975, pemerintah yang diwakili Departemen Agama mengumumkan penunjukan sebuah panitia persiapan pembentukan majelis ulama tingkat nasional. Empat nama yang disebut duduk dalam panitian itu: H. Sudirman, pensiunan Jenderal Angkatan Darat selaku Ketua dan tiga orang ulama terkenal, DR. Hamka, KH. Abdullah Syafei dan KH. Syukri Ghozali. ${ }^{23}$

Dalam pandangan Soeharto, lembaga semacam MUI ini dipandang penting karena dua alasan. Pertama, keinginan pemerintah agar kaum Muslimin bersatu. Kedua, kesadaran bahwa masalah yang dihadapi bangsa tidak bisa diselesaikan tanpa keikutsertaan ulama. ${ }^{24}$ Namun argumen normatif ini diragukan banyak kalangan. Soeharto sebenarnya bukan sedang menyanjung ulama, tapi sebagai berupaya bagaimana pemerintah dapat mengontrol para ulama hingga level paling bawah. Karena itu, struktur MUI dibuat menyerupai ormas, dari pusat sampai kecamatan meskipun dia tidak mempunyai akar. Akar MUI diasumsikan mengikuti akar dari ormas yang terlibat di dalamnya. NU dan Muhammadiyah sebagai organisasi besar di negeri ini menjadi penopang utamanya. Tapi belakangan, ormas-ormas kecil lain semacam Hazbut Tahrir Indonesia (HTI), Majlis Mujahidin Indonesia

\footnotetext{
${ }^{23}$ Muhammad Atho Mudzhar, Fatwa-fatwa Majelis Ulama Indonesia: Sebuah Studi tentang Pemikiran Hukum Islam di Indonesia 1975-1988, (Jakarta: INIS, 1999), h. 5.

${ }^{24}$ Moch Nur Ichwan, "Ulama, State and Politics," dalam Islamic Law and Society, Vol. 12. No. 1, 2005, p. 48.
} 
(MMI) dan sebagainya menjadi bagian dari MUI, bahkan tampak mendominasi. $^{25}$

Cara ini pada awalnya memang sangat efektif untuk mengontrol aktivitas ulama dan masyarakat. Hal ini terbukti dalam proses pemilihan pengurus MUI di semua tingkatan, keterlibatan dan intervensi pemerintah sangat terasa. Di tingkat pusat misalnya, siapa yang hendak diajukan sebagai ketua umum selalu harus dimintakan restu terlebih dahulu kepada Soeharto. Oleh karena Soeharto penguasa yang sangat antipati terhadap NU, maka sepanjang kekuasaannya ia tidak pernah memberi restu kepada kiai dari NU untuk menjadi ketua umum MUI. Namun situasi ini berubah pada masa reformasi, dimana setelah Soeharto turun tokoh NU, KH. Sahal Mahfudh, menjadi ketua umum MUI.

Tidak sekedar kontrol, Soeharto juga berkepentingan untuk menjadikan para ulama MUI sebagai basis legitimasi kebijakan-kebijakannya. Para ulama diposisikan tidak lebih sebagai penyambung lidah dan kaki tangan rezim Soeharto. Tidak heran, selama orde baru banyak sekali fatwa-fatwa MUI yang melegitimasi kebijakan Soeharto seperti soal Keluarga Berencana, pembudidayaan dan memakan daging kodok, pemotongan hewan dengan mesin dan sebagainya. Hal ini cukup menjadi penjelasan, MUI memang dibentuk untuk mengambil posisi demikian.

Sikap MUI mulai berubah ketika Gus Dur (Abdurrahman Wahid) menjadi presiden. Itu pun tampaknya lebih merupakan sikap emosional dan reaktif atas sejumlah kritik yang dilancarkan Gus Dur terhadap MUI, baik sebelum maupun sesudah jadi presiden. Gus Dur misalnya pernah mengusulkan untuk membubarkan MUI. Kalau mau tetap bertahan, menurut Gus Dur, MUI mestinya mencari dana sendiri atau dana abadi tanpa perlu minta jatah kepada Depag RI. Gus Dur juga menyarankan agar MUI tidak berkantor di Masjid Istiqlal. Menghadapi serangan tersebut, barulah MUI mengambil sikap keras kepada pemerintah, persisnya kepada Gus Dur.

MUI misalnya mengajukan keberatan terhadap usulan Presiden Gus Dur untuk mencabut TAP MPRS No. XXV/1966 yang melarang komunisme. Konfrontasi kembali terjadi ketika MUI mengeluarkan fatwa bahwa Ajinomoto

25 Mengenai infiltrasi gerakan Islam radikal ke tubuh MUI, lihat Ahmad Zainul Hamdi, "Radikalisasi Islam melalui Institusi Semi-Negara: Studi Kasus atas Peran MUI Pasca-Soeharto," Jurnal Istiqra' Ditpertais Depag RI, Vol. 06, No. 01, 2007, h. 85-126. 
haram dikonsumsi karena di dalamnya ada enzim babi. Gus Dur kemudian bereaksi keras atas fatwa tersebut karena mengganggu iklim investasi dan kondisi makro perekonomian.

Dalam perkembangannya, MUI memang mengalami perubahan. Jika sebelumnya lebih sebagai "pelayan penguasa," sejak kongresnya ke-6 pada tahun 2000, MUI mendefinisikan dirinya sebagai "pelayan kepentingan umat". Pertanyaannya, tunaikah tugas dan fungsi pelayanan umat tersebut dijalankan MUI? Apakah fatwa-fatwa yang dikeluarkan MUI telah memberikan solusi bagi problem yang dialami umat, ataukah justru menjadi bagian dari problem.

Di pihak lain, keanggotaan MUI yang terdiri dari ormas-ormas Islam, bukan individu, juga cukup problematis. Karena setiap anggota memiliki jumlah utusan yang sama dan suara yang sama, sehingga meski NU dan Muhammadiyah jumlah anggotanya paling besar, tetapi mereka memiliki bobot suara yang sama dengan ormas-ormas yang jumlah anggotanya kecil. Dengan kata lain, meskipun orang $\mathrm{NU}$ dan Muhammadiyah memiliki pandangan moderat, tetapi karena bobot suaranya sama dengan ormas kecil yang berpikir ekstrem maka keluarlah fatwa-fatwa yang bernada ekstrem.

Namun, bukan itu yang menjadi pokok masalahnya. Hal yang jauh lebih krusial adalah sikap pemerintah terhadap fatwa MUI, terutama menyangkut isu-isu pluralisme dan "aliran sesat". Kekhawatiran ini bukan hal yang mengada-ada. Kalau kita simak pidato Presiden Susilo Bambang Yudhoyono (SBY) dalam pembukaan Munas MUI ke-7 yang dilaksanakan 26-29 Juli 2005 hal itu jelas tergambar. Dalam kesempatan itu Presiden SBY menghendaki agar MUI menjadi penjuru dan berperan secara sentral menyangkut akidah keislaman. "Dengan demikian, akan jelas bedanya mana-mana yang merupakan wilayah pemerintahan dan mana-mana sebaiknya negara atau pemerintahan mendengarkan pandangan MUI dan para ulama". (Kompas, 27/7/05)

Secara tidak disadari pernyataan ini mendorong Indonesia menjadi negara teokrasi, karena kebijakannya tidak didasarkan pada konstitusi, tapi pada "fatwa agama," apalagi kalau fatwa tersebut hanya mendengarkan suara MUI. Hal ini jelas sangat membahayakan bagi kehidupan demokrasi di Indonesia.

Pandangan demikian, cukup merisaukan, karena secara tidak disadari Presiden telah memberi angin kepada MUI untuk menjadi "polisi akidah" 
keislaman. MUI diberi otoritas untuk menentukan mana Islam "yang benar" dan mana "yang salah". Bahkan, dalam kaitan dengan Peraturan Presiden No. 36 tahun 2005, MUI memberi otoritas pada dirinya untuk menentukan mana yang yang disebut maslahat untuk kepentingan umum, dan mana untuk kepentingan pribadi. Atas dasar fatwa maslahat untuk kepentingan umum, pemerintah dapat mencabut hak milik pribadi untuk kepentingan umum tersebut. Hal demikian, bukan tidak mungkin MUI akan kembali menjadi "stempel teologis" kepentingan pemerintah yang dikolaborasikan dengan kepentingan pemilik modal.

Munas MUI ke-7 itu menjadi momentum yang sangat penting. Acara ini bisa dikatakan sebagai forum untuk meneguhkan sikap MUI terhadap isu yang dianggap "mengancam kemurnian Islam". MUI mengeluarkan 11 fatwa yang beberapa diantaranya memicu kontroversi. Kesebalas fatwa tersebut adalah: (1) haram pelanggaran hak atas kekayaan intelektual; (2) haram perdukunan dan peramalan; (3) haram doa bersama antar agama, kecuali doa menurut keyakinan masing-masing. Orang Islam hanya boleh mengamini doa yang dipimpin orang Islam. Doa bersama antar agama dianggap bid'ah dan tidak diajarkan dalam syariah Islam; (4) haram nikah beda agama; (5) haram warisan beda agama, kecuali dengan wasiat dan hibah; (6) MUI mempunyai otoritas mengeluarkan kriteria maslahat atau kebaikan untuk orang banyak; (7) MUI mengharamkan pluralisme (pandangan yang menyamakan semua agama), sekularisme, dan liberalisme; (8) hak milik pribadi wajib dilindungi oleh negara, dan tidak ada hak bagi negara untuk merampas bahkan memperkecilnya. Namun jika berbenturan dengan kepentingan umum, maka kepentingan umum didahulukan (yang berhak menentukan kepentingan umum MUI, penulis); (9) Ahmadiyah adalah aliran sesat dan berada di luar Islam. Pengikut Ahmadiyah adalah murtad; (10) perempuan haram menjadi imam shalat selama ada laki-laki yang aqil-balig; (11) MUI memperbolehkan hukuman mati untuk tindak pidana berat.

Terutama menyangkut isu pluralisme dan hubungan antar agama, fatwa-fatwa tersebut menuai banyak protes, karena dianggap mempertajam segregasi sosial, set back, dan merusak keharmonisan hubungan antar agama yang dirajut dengan susah payah. Oleh karena itu, tokoh seperti KH. Abdurrahman Wahid (Gus Dur) yang dengan susah payah membangun sikap saling menghargai dan mempercayai antar pemeluk agama, bersuara lantang agar masyarakat mengabaikan fatwa MUI tersebut (Kompas, 30/7/05). 
Bukan sekali ini saja fatwa MUI mengundang kontroversi. Sebelumnya, MUI pernah mengeluarkan fatwa pengharaman bertransaksi dengan bankbank konvensional karena dianggap mempunyai unsur riba. Orang Islam hanya diperbolehkan bertransaksi dengan bank syariah. Namun, fatwa tersebut tidak mempunyai dampak apapun. Masyarakat seolah tidak menghiraukan fatwa tersebut, dan tetap bertransaksi dengan bank konvensional. Hal yang sama juga pernah terjadi pada pertengahan 1980-an ketika MUI mengharamkan orang Islam memberi ucapan selamat natal kepada kalangan Kristiani. Namun fatwa yang berdalih untuk melindungi akidah Islam tersebut sekedar memicu kontroversi, namun efektivitas untuk mempengaruhi perilaku masyarakat masih dipertanyakan.

Meski masyarakat tidak akan begitu peduli dengan fatwa-fatwa tersebut, namun dalam konteks kehidupan berbangsa dan bernegara fatwa-fatwa tersebut terasa mengganggu, bahkan tidak menutup kemungkinan fatwa tersebut akan membawa dampak yang lebih buruk, terutama dalam konteks hubungan antar agama. Keberagamaan juga menjadi sangat dangkal. Hal ini membuktikan bahwa problem kehidupan beragama di Indonesia bukan terletak pada masyarakat, tapi pada elit-elit agama. Pada lapisan inilah, agama sering dipolitisir untuk kepentingan tertentu, dan senantiasa diletakkan dalam konteks persaingan satu agama atas yang lain.

MUI tentu saja mempunyai hak untuk berfatwa apa saja. Dalam negara demokrasi, tidak ada orang atau kelompok orang yang bisa melarang orang atau kelompok lain untuk mengeluarkan pikiran dan pendapat. Konstitusi Indonesia secara eksplisit dan tegas memberi jaminan hal itu. Oleh karena itu, hal yang mengkhawatirkan bukanlah terletak pada fatwa MUI itu sendiri, tapi efek yang mungkin ditimbulkan. Meski mayoritas masyarakat akan mengabaikan fatwa-fatwa tersebut, namun kita juga tidak bisa menutup mata bahwa ada sekelompok masyarakat yang terkadang membenarkan tindakan anarkhis dan kekerasan berdasar fatwa MUI. Kasus penyerangan dan pembubaran komplek Jemaat Ahmadiyah Indonesia (JAI) di Parung, Bogor tahun 2005 lalu merupakan bukti yang paling telanjang mengenai hal ini. Kelompok yang melakukan kekerasan terhadap JAI menjadikan fatwa MUI tahun 1980 yang menyebutkan Ahmadiyah Qadian sebagai aliran sesat.

Sayangnya, MUI mengabaikan faktor sosiologis dan dampak yang ditimbulkan dari fatwa tersebut. Buktinya, alih-alih mencabut fatwa sesat ter- 
sebut atau mengutuk sekelompok orang yang melakukan tindak kekerasan, dalam Munas ke-7, MUI justru memperkuat fatwa penyesatan terhadap Ahmadiyah. Fatwa ini seperti bensin yang disiramkan ke api. Ia menjadi "energi teologis" tambahan bagi sekelompok orang yang ingin menggusur Ahmadiyah dari bumi Indonesia. Saya tidak bisa membayangkan, jika ada orang yang mengikuti fatwa MUI yang menganggap Ahmadiyah sebagai murtad, dimana orang murtad boleh dibunuh (man baddala dinnahu faqtulūhu). Kemudian, secara diam-diam anggota JAI yang dianggap murtad tersebut dibunuh dengan dalih melaksanakan perintah agama. Sangat mengerikan!

MUI semakin meneguhkan pandangan-pandangan keagamaannya yang cukup radikal. Pada 4-6 November 2007 MUI menyelenggarakan Rapat Kerja Nasional di Hotel Sari Pan Pasific di Jalan Thamrin Jakarta. Dari acara tersebut MUI mengeluarkan sepuluh panduang untuk mendeteksi aliran sesat. Sepuluh panduan itu adalah: (1) mengingkari salah satu dari rukun iman yang enam; (2) meyakini dan atau mengikuti akidah yang tidak sesuai dengan alQur'an dan sunnah; (3) meyakini turunnya wahyu setelah al-Qur'an; (4) mengingkari otentisitas dan atau kebenaran isi al-Qur'an; (5) melakukan penafsiran al-Qur'an yang tidak berdasarkan kaidah-kaidah tafsir; (6) mengingkari kedudukan hadits nabi sebagai sumber ajaran Islam; (7), menghina, melecehkan dan atau merendahkan para nabi dan rasul; (8) mengingkari Nabi Muhammad sebagai nabi dan rasul terakhir; (9) mengubah, menambah dan atau mengurangi pokok-pokok ibadah yang telah ditetapkan oleh syariah, seperti haji tidak ke baitullah, shalat wajib tidak lima waktu), dan (10) Mengkafirkan sesama Muslim tanpa dalil syar'i seperti mengkafirkan Muslim hanya karena bukan kelompoknya.

Sebelum MUI mengeluarkan panduan tersebut, sejak bulan Juli 2007, isu aliran keagamaan yang dianggap sesat sudah mulai menjadi isu publik. Beberapa isu yang muncul antara lain soal Ahmadiyah yang menjadi sorotan publik sejak Mei 2005 ketika Markas Ahmadiyah di Parung diserang massa yang dipimpin Abdurrahman “Umarella” Assegaf. Sebelum itu, Mei 2007, ada peristiwa penyesatan terhadap kelompok Islam Sejati (Lebak) oleh MUI Banten; penyesatan terhadap komunitas Wahidiyah oleh MUI Kabubaten Tasikmalaya (Juni 2007); penyesatan terhadap al-Qiyadah al-Islamiyyah yang diawali oleh MUI DIY (September 2007); nabi palsu Rusmiyati binti Sawabi 
Sastrawiharja (September 2007) yang disesatkan MUI Kota Madiun; Jamaah dzikir Asmaul Husna Garut (Oktober 2007).

Karena itu, prakarsa MUI mengeluarkan sepuluh panduan untuk mendeteksi aliran sesat merupakan jawaban dari peristiwa-peristiwa yang terjadi sebelumnya, sebagaimana diuraikan di atas. Dengan panduan tersebut, MUI daerah dan kelompok-kelompok masyarakat mempunyai legitimasi untuk membenarkan aksi-aksinya. Hal ini bisa dilihat, setelah MUI mengeluarkan panduan, aksi-aksi untuk men-sweeping kelompok yang dianggap sesat semakin marak terjadi.

Pada November 2007 ada beberapa kasus penyesatan: (1) Kelompok pengajian Hidup di Balik Hidup yang disesatkan MUI Kab. Cirebon; (2) Islam Model Baru Jambi oleh MUI Jambi; (3) Suku Dayak Losarang Indramayu oleh MUI dan PAKEM Indramayu; (4) Tarekat Naqsabandiyah Bulukumba; (5) Kelompok pengajian Nurul Yakin Tangerang. Desember 2007: (1) Ponpes Miftahul Huda Serang; (2) Padepokan Syafa'atus Shalawat Malang. Januari 2008: (1) Fatwa sesat dan larangan penyelenggaraan "Maulid Hijau" oleh warga Desa Tegalrandu (salah satu desa di Kec. Klakah Lumajang) oleh MUI Klakah Lumajang; (2) Ahmad Sayuti (76 th) penulis buku Kelalaian Para Pemuka Agama dalam Memahami Kitab-kitab Peninggalam Nabi dan Rasul Allah diklaim sesat oleh MUI Jabar dan PW Persis Jabar; (3) Penyerangan Kelompok Pengajian Satariyah Syahid di Balalawan Medan. Maret 2008: (1) Penyesatan terhadap aliran Kandang Rasul Lembaga Mahkamah Potensi Rakyat Suku Bahasa, Bangsa, Negara, Potensi Alam dan Segala Isinya di Lebak Banten oleh MUI Lebak; (2) penyesatan terhadap tokoh-tokoh Islam Model Baru (IMB) Jambi diadili dengan tuduhan melakukan penodaan agama. April 2008 Badan Koordinasi dan Pengawasan Aliran Kepercayaan Masyarakat (Bakorpakem) mengeluarkan peringatan keras kepada JAI, karena dianggap tidak secara serius melaksanakan 12 penjelasan tentang pokok-pokok keyakinannya. Juni 2008 Pemerintah mengeluarkan SKB Tiga Menteri No. 3 Tahun 2008, No. Kep-033/A/JA/6/2008, dan No. 199 Tahun 2008 yang melarang aktivitas JAI.26

Dari data tersebut bisa dibaca, MUI dalam berbagai tingkatan memainkan peran yang sangat dominan dalam isu aliran sesat. MUI di berbagai

${ }^{26}$ Lihat Monthly Report on Religious Issues edisi 1-12, Juli 2007-Juni 2008. 
daerah senantiasa menjadi aktor utamanya. Hampir tidak ada kasus penyesatan yang tidak melibatkan MUI. Kalau arus penyesatan dipandang sebagai ancaman terhadap hak asasi manusia dan kebebasan beragama, maka MUI -suka atau tidak- menjadi bagian dari ancaman tersebut. Memang, tidak semua eksponen MUI mempunyai pikiran seperti ini, namun tren MUI menjadi "polisi agama" menguat dimana-mana.

Hal ini menandai dua hal sekaligus. Di satu sisi hal ini bisa dibaca sebagai pertanda bahwa MUI menjadi institusi keagamaan yang semakin "bergigi," dan di sisi lain hal ini juga pertanda menguatnya kelompok fundamentalis melalui institusi agama yang kelahirannya diinisiasi pemerintah orde baru. MUI, baik pusat maupun daerah kembali menunjukkan dirinya sebagai sebagai kekuatan yang dianggap paling otoritatif untuk menentukan sesat tidaknya sebuah kelompok dan aliran keagamaan. Otoritas MUI ini semakin bertambah ketika Presiden Susilo Bambang Yudhoyono menyatakan akan mengikuti fatwa-fatwa MUI. Pernyataan Presiden tersebut mengindikasikan betapa ia merasa inferior ketika berhadapan dengan MUI.

\section{Kesimpulan}

Dari ilustrasi tersebut otoritas keagamaan (Islam) di Indonesia cukup problematik. Meskipun secara teoritik otoritas itu tersebar dalam berbagai lapisan, namun belakangan otoritas MUI sebagai pemegang kendali semakin menguat. Penguatan MUI ini di samping karena dukungan pemerintah yang semakin menguat, tapi posisi sosial-politiknya juga semakin kuat.

Hal ini antara lain bisa dilihat dari sejumlah UU yang secara khusus menyebut MUI. Setidaknya ada dua UU yang secara eksplisit menyebut MUI, yaitu: pertama, UU No. 40 Tahun 2007 tentang Perseroan Terbatas. Hal ini terdapat dalam pasal 109 ayat (2): "Dewan Pengawas Syariah sebagaimana dimaksud pada ayat (1) terdiri atas seorang ahli syariah atau lebih yang diangkat oleh RUPS atas rekomendasi Majelis Ulama Indonesia".

Kedua, UU No. 21 Tahun 2008 tentang Perbankan Syariah. Dalam UU ini setidaknya ada dua pasal yang menyebut MUI, yaitu pasal 26 dan pasal 32 . Dalam pasal 26 ayat (2) disebutkan: "Prinsip syariah sebagaimana dimaksud pada ayat (1) difatwakan oleh Majelis Ulama Indonesia". Ayat (3) disebutkan: "Fatwa sebagaimana dimaksud pada ayat (2) dituangkan dalam Peraturan 
Bank Indonesia". Dari pasal ini jelas, dalam hal ekonomi syariah fatwa MUI legal binding dan menjadi satu-satunya dasar pembuatan Peraturan Bank Indonesia dalam hal penentuan prinsip syariah dalam ekonomi.

Dalam pasal 32 (2) yang menjelaskan soal Dewan Pengawas Syariah, juga disebutkan: "Dewan Pengawas Syariah sebagaimana dimaksud pada ayat (1) diangkat oleh Rapat Umum Pemegang Saham atas rekomendasi Majelis Ulama Indonesia". Pasal ini sebenarnya mengulang dari UU tentang Perseroan Terbatas dimana MUI menjadi satu-satunya lembaga yang bisa merekomendasi Dewan Pengawas Syariah.

Dari penjelasan di atas, MUI nyata sudah menjadi lembaga "semi negara," tidak bisa disamakan dengan ormas-ormas lain semacam NU dan Muhammadiyah. Dalam hal fatwa ekonomi syariah, MUI menjadi satu-satunya lembaga yang akan diikuti pemerintah, legal binding. Hal ini antara lain yang menyebabkan, mengapa dalam urusan-urusan selain ekonomi syariah, MUI sering memaksakan pendapat dan fatwanya menjadi kebijakan pemerintah. $^{27}$

Kalau sekedar fatwa yang terkait dengan masalah furüiyyah-fiqhiyyah fatwa MUI memang bisa diabaikan jika ternyata justru jadi masalah. Namun fatwa dalam bidang ekonomi syariah, fatwa MUI bisa dikatakan legal binding. Karena posisi itu, MUI menginginkan agar kekuatan fatwa MUI yang legal binding tidak hanya terkait dengan ekonomi syariah, tapi dalam semua urusan keagamaan.

Fatwa dalam diskursus hukum Islam bukanlah sekedar pendapat tentang sesuatu yang bersifat sekuler, namun fatwa mengandaikan bahwa pendapat itu "mewakili" pendapat Tuhan. Oleh karena itu, fatwa harus dikeluarkan oleh orang yang mempunyai otoritas. Karena klaim otoritatif inilah, fatwa sering menggiring orang atau sekelompok orang bersifat otoriter dengan fatwa yang dikeluarkan. Sikap otoriter itu didasarkan pada asumsi bahwa apa yang difatwakan adalah pendapat Tuhan itu sendiri. Yang tidak mengikuti pendapat fatwa tersebut dianggap melawan pendapat Tuhan. Padahal, otoritas hukum

27 Lebih jauh lihat Laporan Toleransi Beragama 2008 yang dikeluarkan The Wahid Institute, "Menapaki Bangsa yang Kian Retak". Laporan ini di-launching pada 10 Desember 2008 di Hotel Bintang Jakarta. 
sepenuhnya ada dalam diri Tuhan. Oleh karena itu, manusia seotoritatif apapun tidak bisa sepenuhnya mewakili pendapat Tuhan.

Dengan demikian, fatwa-fatwa MUI tersebut tetap saja tidak bisa dikatakan sebagai satu-satunya yang mewakili pendapat Tuhan. Pendapat fiqih tetap dalam karakternya hanya mengikat bagi yang mempercayai (mulzim binafsihi). Meski secara istinbātiy (prosedur penetapan hukum) mungkin benar, tapi ia tidak secara serta merta bisa diterapkan (tațiiqiy). Oleh karena itu, fatwa MUI bukanlah akhir dari semuanya.

Akhirnya, penulis menyadari sepenuhnya bahwa ilustrasi di atas belum bisa menjelaskan secara lebih komprehensif problem yang terkait dengan kompleksitas masalah otoritas keagamaan. Namun, dari tulisan tersebut terlihat bahwa ada bahaya yang mengancam apabila otoritas agama berselingkuh dengan otoritas negara. Oleh karena itu, yang paling masuk akal adalah bagaimana menumbuhkan kepercayaan kepada umat Islam agar tidak selalu berpikir bahwa kesempurnaan agama baru terjadi jika agama tersebut menyelinap, bahkan menjadi negara itu sendiri.[w] 


\section{BIBLIOGRAFI}

Asymawi, Muhammad Said al-, al-Islām al-Siyāsi, Kairo: Sina Linnasyr, 1978.

Carter, April, Otoritas dan Demokrasi, Jakarta: Rajawali Press, 1979.

Fadl, Khaled Abou el-, Atas Nama Tuhan, dari Fikih Otoriter ke Fikih Otoritatif, Jakarta: Serambi, 2004.

Friedman, dalam R. Flatham (ed.), Concept in Social and Political Philosophy, New York: McMilaan, 1973.

Hamdi, Ahmad Zainul, "Radikalisasi Islam melalui Institusi Semi-Negara: Studi Kasus atas Peran MUI Pasca-Soeharto," Jurnal Istiqra' Ditpertais Depag RI, Vol. 06, No. 01, 2007.

Hitti, Philip K, History of the Arabs, London: Macmillan Press Ltd, 1974.

Ichwan, Moch Nur, “Ulama, State and Politics," Islamic Law and Society, Vol. 12. No. $1,2005$.

Iqbal, Muhammad, Dr., Fiqh Siyasah: Kontekstualisasi Doktrin Politik Islam, Jakarta: GMP, 2007.

Khallaf, Abd al-Wahhab, 'Ilmu Ușūl al-Fiqh, Kairo: Maktabah al-Da'wah alIslamiyyah, 1990.

Monthly Reporton Religious Issues edisi 1-12, Juli 2007-Juni 2008.

Mudzhar, Muhammad Atho, Fatwa-fatwa Majelis Ulama Indonesia: Sebuah Studi tentang Pemikiran Hukum Islam di Indonesia 1975-1988, Jakarta: INIS, 1999.

Na'im, Abdullahi Ahmed an-, Dekonstruksi Syariah, Yogyakarta: LKiS, 1994.

Islam dan Negara Sekuler, Menegosisikan Masa Depan Syariah, Bandung: Mizan, 2008.

The Wahid Institute, "Menapaki Bangsa yang Kian Retak." Laporan Toleransi Beragama 2008.

Vatikiotis, P.J., Islam and the State, London: Rouledge: 1987.

Walisongo, Volume 20, Nomor 1, Mei 2012 
